\section{Original} Article

\begin{tabular}{|l|}
\hline Access this article online \\
\hline Website: \\
http://ajobe.journals.ac.za/ \\
http://dx.doi.org/10.15249/6-1-10 \\
Quick Response Code: \\
\hline
\end{tabular}

Address for correspondence: Dr. Theo H Veldsman, Department of Industrial Psychology and People Management, University of Johannesburg, P.O. Box 524, Auckland Park 2006, Johannesburg, South Africa. E-mail: theov@uj.ac.za

\title{
The soft underbelly of corporate governance (Part 1): The hardware of board dynamics
}

\author{
Theo H. Veldsman
}

Department of Industrial Psychology and People Management, University of Johannesburg, South Africa

\section{ABSTRACT}

In spite of the abundance of corporate governance codes, legislation to ensure compliance and stock exchange reporting requirements, corporate failures still persist because of poor governance. It can be argued that though the 'rules of the road' - codes, legislation, and requirements - are in place, the chances of governance failure will remain high if explicit attention is not given to 'soft' governance: The "black box of what happens behind the boardroom door" in terms of board dynamics. The relatively unstudied people side of boards remains the soft underbelly of corporate governance; its Achilles heel. The aim of this two-part paper is to address the elements affecting board dynamics and board performance, together with the consequential implications for corporate governance. A conceptual framework for soft governance is proposed by means of which board dynamics and performance can be explored and studied. This is Part 1 of the two-part article.

Key words: Board dynamics, Board performance, Board effectiveness, Corporate governance, Soft governance

\section{ORIENTATION}

The growing importance of corporate governance

Corporate governance (from the original Greek, and later latinised, for "to steer, direct") has been described as the biggest issue facing business in the $21^{\text {st }}$ century, especially in light of a number of significant corporate failures attributed directly, in many instances, to breakdowns in governance (Brountas, 2004, King II, 2002; Rezaee, 2009). This, in spite of an abundance of corporate governance codes, e.g., the UK Cadbury Code, the UK Combined Code, the South African King Code, the German Cromme, and the Dutch Tabaksblat, and legislation to ensure compliance, like the USA Sarbanes-Oxley and stock exchange reporting requirements. In some quarters, it is argued that corporate governance is in crisis (Garratt, 2003; MacAvoy and Millstein, 2003). It may even be fatally flawed (Chew and Gillian, 2005). If corporate governance is the most significant business issue of this century and currently in crisis or even fatally flawed, then the domain of corporate governance faces a major challenge going forward.
The growth in the importance of corporate governance in recent years can be attributed to at least the following reasons:

- The newly emerging order, typified by accelerating, radical, and discontinuous change, blossoming diversity, bewildering ambiguity, increasing complexity, heightened interdependency, and increasing boundarilessness (Veldsman, $2002 ; 2008)$, is necessitating more checks and balances on the actions and conduct of organisations and their members. This is particularly relevant in the prevention of the emergence of corporate buccaneers who capitalise on and exploit these conditions through unethical operations (Brountas, 2004, Chew and Gillian, 2005; Garratt, 2003; Naidoo, 2009; Rezaee, 2009);

- The need to take greater business risks, with the associated ethical ambiguities and implications, in an increasingly uncertain and unpredictable world (Garratt, 2003; Rezaee, 2009);

- An ever-widening group of more diverse stakeholders with multiple needs/ interests, accompanied by increasing stakeholder (including shareowner) activism (Brountas, 2004, Conger, Lawler and Finegold, 2001; Daily, Dalton and 
Cannella, 2003; Finegold, Benson and Hecht, 2007; Garratt, 2003; King III, 2002; Naidoo, 2009; Rezaee, 2009);

- A heightened expectation of organisations to be more visibly ethical, and demonstrate more concrete corporate citizenship conduct (King II, 2003; King III, 2009; Rezaee, 2009; Tricker, 2009);

- The growing pressure on organisations to maintain, in an uncompromising way, the fine line between performance and conformance (Charan, 2005; Garratt, 2003; 2010; King II, 2003; Nadler, Behan and Nadler, 2006);

- The growing legislative enforcement of directors' fiduciary accountability and personal liability for the organisations they oversee, with the consequential criminal prosecution of non-compliance. Being a director is no longer a 'soft,' prestigious appointment with no real accountability and only perks and status (Chew and Gillian, 2005; Garratt, 2003; 2012; Leblanc and Schwartz, 2007); and

- The significant increase in the size of organisations, which makes some of them seem "too big to fail," significantly increasing the risk of whole system implosion or meltdown. The financial sector as the trigger of the 2008/2009 recession is a recent, prime example. The primary cause of this recession has been attributed to a near catastrophic breakdown in corporate governance of, in particular, risk management. At present, a similar crisis is facing the Eurozone.

The fundamental premise is that better corporate governance will create more sustainable wealth for stakeholders. It has been found that investors are willing to pay a premium for better governed companies. This premium is even higher if the companies are located in developing countries/emerging economies (McKinsey, 2002; Naidoo, 2009).

\section{Defining corporate governance}

Informally defined, corporate governance pertains to ensuring that the right people in the organisation consistently do the right things, for the right reasons, in the right way, at the right time, with the right autonomy. Put differently, corporate governance is doing things properly, with the right authority and accountability (Huse, Minichilli and Shøning, 2005).

More formally defined, corporate governance refers to ensuring that an organisation conducts its business in an ethical, legitimate, fair, and credible manner with respect to its current performance and future sustainability, whilst balancing the multiple interests of its diverse stakeholders. The ultimate aim of corporate governance is to ensure that the business of the organisation within a certain context is conducted in such a way as to make and keep the organisation a going concern for all its stakeholders through ongoing wealth creation - now and in the future (Bain,
2008; Brountas, 2004, Daily, Dalton and Cannella, 2003; Huse, Minichilli and Shøning, 2005; Murphy and McIntyre, 2007; Naidoo, 2009; Rezaee, 2009; Tricker, 2009).

The multi-dimensionality of corporate governance It can be argued that corporate governance is multidimensional in nature:

- Content and process: On the one hand, governance has a content dimension: The "what" of governance. For example, the clear separation of the roles of the chairperson and CEO, on the other hand a process dimension: The "how" of governance: For example, how the duties of the chairperson and CEO are separated in practice.

- Letter and spirit: On the other hand, one can act according to the letter of and/or the spirit of a governance code. For example, most codes explicitly state that the corporate chairperson must be an independent, outside person, which is the letter of a code. The spirit of a code would imply that the chairperson as an independent, outside person needs to be a strong enough person, able to direct and guide the board in an uncompromising, impartial, and objective manner in the interests of all stakeholders. The spirit requires reading 'between the lines' of a code, and interpreting and understanding the intention of its formally codified guidelines. The letter of a code therefore pertains more to the 'hard' side of governance - what has formally been set down on paper, with which the organisation must comply. The spirit of a code - what is intended and aspired to refers more to the 'soft' side of governance (cf. Garratt, 2003). The intention of the present article is to address soft governance as it manifests in board dynamics, in terms of both content and process.

Different permutations of sound governance arise out of the above dimensions. For example, content and/ or process wise the organisation can follow the letter of a governance code, but not the spirit thereof: the election of an independent, outside chairperson. This person is however, not strong enough to provide proper, independent leadership to the board, perhaps because it suits a certain grouping(s) on the board which wishes to use the board for its own self-interest. Or, content and process wise the organisation can comply with both the letter and spirit of a code, and so forth.

Corporate failures frequently arise out of the first permutation given above - adherence to the letter but not the spirit of a corporate governance code. This occurs because most, if not all, of the current corporate governance codes deal predominantly (or perhaps even exclusively) with the letter (ie., hard governance) and not the spirit dimension (i.e, soft governance) of governance. Acting according to the letter of codes regarding content and process is often seen as the 'silver bullet' that will minimise or even prevent governance 
failures. The oversight of codes not encouraging boards to act according to the spirit of a corporate governance code has truly become the soft underbelly of governance, its Achilles heel.

Bain (2008), for example, focuses only on hard governance in his review of board effectiveness, although he acknowledges the role of soft governance. Naidoo (2009), in her comprehensive guide on corporate governance, spends only three pages on the soft side of corporate governance by discussing the creation of the right boardroom culture. Her list of characteristics of good governance pertains only to hard governance, with no reference to soft governance. The same criticism also applies to Barker and Anderson (2010), Main (2010), and Wixley and Everingham (2005), who all refer only to hard corporate governance in their respective comprehensive coverage of the topic. Charan (2005), Garratt (2003), Huse, Minichilli and Shøning (2005), Leblanc and Schwartz (2007), Vandewaerde, Voordeckers, Lambrechts and Bammens (2011), and Zona and Zattoni (2007) are rare exceptions in this regard in that they pay significant attention to soft governance by putting board dynamics centre stage with respect to an effective board.

It will be proposed in the ensuing discussion that soft governance embrace a range of elements that are not addressed by conventional governance codes, essentially elements pertaining to the 'people side' of boards. People, i.e. the members of the board, are, after all, central to the success of a board, analogous to the organisation, also consisting of people, which a board oversees. Codes unintentionally encourage organisations to pay attention only to the hard content/process, letter aspects of governance and, by default, to underplay or ignore the soft content/process, spirit aspects.

It has been argued, however, that a dire need exists for a behavioural theory on board dynamics and functioning soft governance - and, by implication, of board performance (Leblanc and Schwartz, 2007; Minichilli, Zattoni and Zona, 2009; Vandewaerde, Voordeckers, Lambrechts and Bammens, 2011; Van Ees, Gabrielsson and Huse, 2009). Given the persistence of corporate governance failures, attention thus need to be given, as a matter of pressing urgency, to the "black box of what really happens behind the boardroom door" in terms of soft corporate governance, which is the intention of this article (Daily, Dalton and Cannella, 2003; Leblanc and Schwartz, 2007; Minichilli, Zattoni and Zona, 2009; Vandewaerde, Voordeckers, Lambrechts and Bammens, 2011; Zona and Zattoni, 2007).

In support of corporate governance codes, however, it can be contended that the intention of these codes has all along been to address the 'rules of the game,' operationalised as corporate governance guidelines, i.e. hard governance. Their intention was never to propose guidelines regarding the 'players,' i.e. board members, with their interactions and dynamics affecting the day-to-day interpretation and application of the rules in terms of the players' chosen 'game plan,' i.e. soft governance. If this is the case, and to pro-actively prevent codes from being seen as the total and final answer to sound governance in the future, codes should be expanded to contain guidelines regarding the appropriate people preconditions and enablers to be present in order to enhance the chances of codes being adhered to, both in content and process, as well as in letter and spirit.

\section{The purpose of the article and topics covered}

The purpose of this two-part article is to explore the elements affecting sound soft corporate governance - the people side of boards. It is the premise of this article that adherence to the spirit of corporate governance, or not, can be attributed to the dynamics between and amongst the directors of a board, who carry the ultimate accountability for the corporate governance of an organisation. In turn, the board dynamics will directly and significantly affect the probability that sound corporate governance will be a lived, practised reality in its full dimensionality, as discussed above.

The aim of the article is therefore to build an in-depth and comprehensive understanding of board dynamics as a way to protect the soft underbelly of governance, i.e. soft governance. It is, in the final instance, the directors as people who make up a board and who make that board perform effectively. This article aims to propose a conceptual model of soft governance in terms of which board dynamics can be explored and understood.

In this article the term 'board' is used as representative of any entity that performs the overseeing role and has ultimate corporate governance accountability for an organisation. Thus, the council of a university or a board of trustees of a non-government organisation or a school would also fall within the ambit of this article.

The article addresses the following topics: firstly, the unique character of a board as a group that needs to become a team; secondly, a map of the 'performance space' of a board, which charts the elements of soft governance; and, thirdly, the specific elements of a board's performance space as considered from the vantage point of board dynamics. Part 1 of the article addresses the unique character of a board as a group that has to become a team, the performance space of a board, and the 'hardware' (the term is defined below) of the board set-up.

\section{THE UNIQUE CHARACTER OF A BOARD AS A GROUP THAT NEEDS TO BECOME A TEAM}

The board of directors of an organisation as a collective body carries the highest and ultimate authority and accountability for protecting the interests of the organisation's stakeholders 
in terms of the actions, actual and intended, present and future, taken by that organisation and its leadership. These are the so-called agency (cf. Anderson, Melanson and Maly, 2007; Daily, Dalton and Cannella, 2003; Garratt, 2003; Murphy and McIntyre, 2007; Tricker, 2009; Zona and Zattoni, 2007) and/or stewardship (cf. Anderson, Melanson and Maly, 2007; Daily, Dalton and Cannella, 2003; Davis, Schoorman and Donaldson, 1997; Tricker, 2009) roles of the board. The agency role has received the most attention in literature. The stewardship role is, however, increasingly being emphasised (Anderson, Melanson and Maly, 2007; Finegold, Benson and Hecht, 2007; Minichilli, Zattoni and Zona, 2009). The board is ultimately accountable to stakeholders for the soundness of an organisation's corporate governance.

A board exercises its authority as a group. It has to take shared, ultimate responsibility and accountability, both jointly and severally, for the actions of the organisation. The power of a board lies in its collective wisdom. This wisdom is only released in a value-adding way when a board functions as a collective body. That is, when a board speaks as one voice from those of many (Charan, 2005).

Being a collective body speaking with one voice implies that a board as a group of individuals must transform itself into a proper (or true) team (Vandewaerde, Voordeckers, Lambrechts and Bammens, 2011). The fact that a board must be seen as a team has been ignored and even denied in past research on boards (Vandewaerde, Voordeckers, Lambrechts and Bammens, 2011). A group refers to a mere collectivity of individuals.

In contrast, a board acting as a genuine team can be described as a limited number of persons who act in a mutually supportive and interdependent manner. Through the differential contributions of its respective members, a board as a team strives to achieve shared intentions and goals within a certain context, for which collective responsibility is taken. In the case of a board, the common, overarching goal is a well-governed organisation that creates value for its stakeholders (Charan, 2005; Conger, Lawler and Finegold, 2001; Curseu, 2009; Murphy and McIntyre, 2007; Nadler, Behan and Nadler, 2006; Payne, Benson and Finegold, 2009; Petrovic, 2008; Zona and Zattoni, 2007).

The unique character of a board as a unique type of team is to be found in at least five dominant features that make it challenging for a board to become a proper team, and not remain merely the sum total of a group of individuals:

- One becomes a board member through a politicallybased election (or, in some instances, even a nomination) process. Board members are expected, whether it is explicitly expressed or not, to represent and serve the parochial interests of the stakeholder(s) they represent - the agency theory on the role of boards (Vandewaerde,
Voordeckers, Lambrechts and Bammens, 2011);

- Board members have high personal profiles and strong personalities. They are often executive leaders in their own right in other organisations. As members of the board, they all are equal in standing, responsibility, and roles (Nadler, Behan and Nadler, 2006; Vandewaerde, Voordeckers, Lambrechts and Bammens, 2011; Zona and Zattoni, 2007);

- Usually, at least $50 \%$ of board members are not employed on a permanent basis by the organisations on whose boards they serve. Board members therefore do not have a full-time involvement in the organisation they oversee (Conger, Lawler and Finegold, 2001; McNulty and Pettigrew, 1999; Nadler, Behan and Nadler, 2006; Payne, Benson and Finegold, 2009: Petrovic, 2008; Vandewaerde, Voordeckers, Lambrechts and Bammens, 2011);

- A low frequency of regular, face-to-face interaction amongst board members - this interaction may occur twice per quarter for a few hours in board and board committee meetings (Conger, Lawler and Finegold, 2001; Marcus, 2008; MacAvoy and Millstein, 2003; Murphy and McIntyre, 2007; Nadler, Behan and Nadler, 2006; Payne, Benson and Finegold, 2009; Vandewaerde, Voordeckers, Lambrechts and Bammens, 2011; Zona and Zattoni, 2007); and

- The duty of solving of complex challenges/issues under severe time constraints with imperfect information (Conger, Lawler and Finegold, 2001; Marcus, 2008; Nadler, Behan and Nadler, 2006; Payne, Benson and Finegold, 2009; Zona and Zattoni, 2007).

In contrast to a board as a unique type of team, members of conventional teams are permanently employed by their organisations. They represent no particular party external to the team or organisation, but serve a common, shared interest, namely that of their organisation. They have clearly contracted roles, responsibilities, authority, and deliverables, and enjoy an unambiguous status in their organisation. Team members have a high frequency of interaction on a daily basis - face-to-face and/or virtually - while fulfilling their roles and duties.

Given the conventional understanding of 'a team,' the challenge for a board to move from being merely a group of individuals to a genuine team therefore indeed is daunting. However, if this transformation does not occur, the likelihood of destructive and unhealthy board dynamics increases, which will sabotage the spirit of sound corporate governance and, consequently, the letter thereof.

The transformation of a board from a group to a team thus requires an in-depth understanding of the performance space of a board and the make-up of each of the elements constituting this space. This will be discussed in the subsequent sections of the article. 


\section{THE PERFORMANCE SPACE OF THE BOARD}

Figure 1, constructed by the author, depicts a proposed map of the performance space of the board, together with its constituent elements. This space in its totality encompasses the domain of soft governance of the board. It is within this performance space that adherence to the spirit of sound corporate governance will dynamically unfold, be nourished and be sustained.

As depicted in Figure 1, the performance space of a board consists of five elements (to be discussed in detail in the balance of the article):

- The board set-up in terms of its hardware and software, (shown in the box at the bottom of the two axes in the figure). The board set-up contains the Pandora's box of things a board has to put in place regarding its task (the hardware) and its process of working together (the software) to create favourable board dynamics and performance conditions. The board hardware sets the outer context (i.e. the playing field) for the board software (i.e. the players and the game) (Marcus, 2008). The board set-up hence encompasses the enablers of sound board dynamics and, consequently, excellent board performance (cf. Marcus, 2008; Petrovic, 2008; Zona and Zattoni, 2007).

- Figure 2 depicts the make-up of the board set-up, the contents of the Pandora's box of elements affecting its dynamics: its hardware and software. As can be deduced from this figure, these elements stand in reciprocally influencing relationships towards each other, hence the two-way arrows.

The board hardware elements, as per Figure 2, are: Positioning of the board, board tasking, board design, board profile, and ethics. Ethics provides the platform from which to leverage the whole of the inner context, and, in turn, infuses the elements contained in the inner context with a certain ethical 'flavour'. Hence the placement of "ethics" within the overall space of

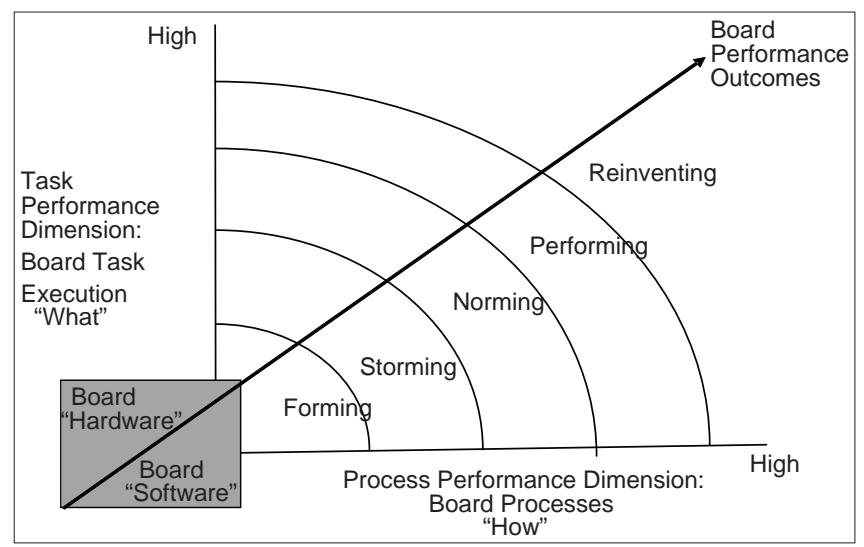

Figure 1: A map of the "performance space" of the board the inner context. The board software elements are: Organisational image, dominant coalition, culture, climate, leadership, personal engagement, power and politics, interaction pattern, and trust. Though the hardware elements set the preconditions for the software elements of the board set-up, the software elements - the board processes - can either strengthen or weaken the hardware elements, however well they have been set up (cf. Bain, 2008):

- The task (i.e. getting the work done; its hardware) and process (i.e. working together; its software) performance dimensions, ranging from low to high (the axes of board performance in Figure 1) (Petrovic, 2008; Zona and Zattoni, 2007);

- The evolutionary life cycle stages of development (the four quarter circles in Figure 1), the stages being forming through to re-inventing, as the board moves along the two performance dimensions (cf. Wheelan, 2005); and

- Performance outcomes (the diagonal in Figure 1), which is a function of the board's evolution or lack thereof through the aforementioned life cycle stages, and thus its progress or lack thereof along the two performance axes.

Overall, the above performance space elements configure systemically into a pattern of board dynamics and performance, forming either a virtuous or a vicious feedback cycle. This cycle, in turn, affects the quality of the corporate governance that manifests, ultimately in board performance (Huse, Minichilli and Shøning, 2005; Vandewaerde, Voordeckers, Lambrechts and Bammens, 2011).

At most, if at all, corporate governance codes deal primarily with the performance space elements of board hardware and the task performance dimension in order to enhance board performance. However, codes mostly assume that these hardware elements are in place. The board software, the process dimension, and the evolutionary developmental stages of soft corporate governance are frequently not

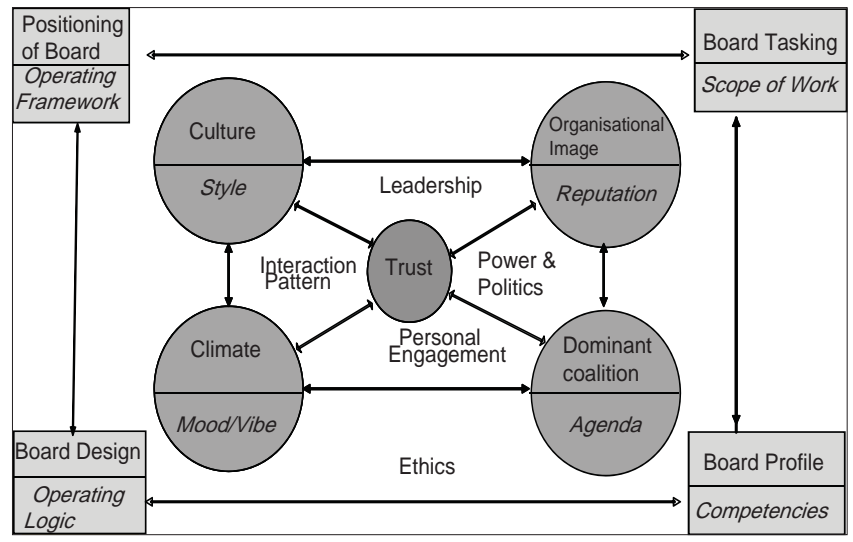

Figure 2: The board set-up elements affecting the board's dynamics: Its hardware and software 
formally addressed by codes, if they are mentioned at all. Each of the five elements of the performance space of the board, as depicted in Figure 1, is next discussed in detail: the hardware in Part 1 of the article, and the software with the balance of the "performance space" elements in Part 2.

\section{THE BOARD SET-UP: ITS HARDWARE}

The board hardware pertains to the formal aspects of a board's functioning. It defines and frames a board's role and mode of working. As has been stated above, the board hardware sets the context (i.e. the playing field) for the board software (the players and the game) (Marcus, 2008). As was indicated above, corporate governance codes frequently assume these elements are in place when these codes discuss board performance.

\section{Hardware element 1: Positioning of a board}

The positioning of a board [Figure 2] refers to the operating framework that needs to be set up as a departure point. This framework is constituted by answering five interdependent questions through explicit, intense board deliberations in order to arrive at a coherent framework:

- Purpose: Why does the board believe it exists? The answer to this question provides the raison d'être for the board - how the board sees its corporate governance role with respect to the organisation which it has to oversee;

- Vision: What 'dream' does the board have for the organisation for which it is performing this oversight role? Put differently, what is the desired end state the board wants to bring about through its value-adding contribution as a board?;

- Mandate: who can act with what degree of autonomy? The answer to this question defines what type of board it wishes to be in terms of its sphere of influence, relative to that of the CEO and the organisation's executive team. Figure 3 depicts three types of boards in terms of mandate (Anderson, Melanson and Maly, 2007; Charan, 2005; Chew and Gillian, 2005; Garratt, 2003; Nadler, Behan and Nadler, 2006; Payne, Benson and Finegold, 2009; Zona and Zattoni, 2007)

- Vantage point: From what perspective will the board view the world and the way this world works (Vandewaerde, Voordeckers, Lambrechts and Bammens, 2011)? Here the board has to debate at least two views regarding the world. Firstly, what are the right set of glasses to use when looking at the world in which the board has to lead? Figure 4, constructed by the author, graphically contrasts two possible lenses through which a board can view the world.

As can be seen from Figure 4, board members can adopt either a Newtonian or complexity/chaos set of glasses in viewing the world (Fitzgerald, 2001; Snowden and Boone, 2007; Stacey, Griffin and Shaw, 2000; Wheatley,
2006). If individual board members use different set of glasses, their interpretation, understanding (or sensemaking), and response modes to board matters will differ significantly, which may result in divisive debates. Board members will literally see the world, and how it works, differently.

Secondly, the board needs to debate the dimensions with which to chart the world. Figure 5, constructed by the author, graphically depicts the possible dimensions a board can use to chart the world. The selected dimensions will determine what shape the board's radar screen will take, allowing certain matters to be observed and debated, or not. At issue here is what matters board members will regard as relevant or not, depending on the dimensions of the world board members consider; and

- Identity: Who and what are we as a board? What is our 'brand' as a board? One way of profiling a board's identity - who and what a board is/wishes to be - is by plotting its identity in terms of a two-dimensional focus a board may adopt: performance vs. relationship and compliance vs. commitment. One of four 'pure,' predominantly constructive identities flow from the

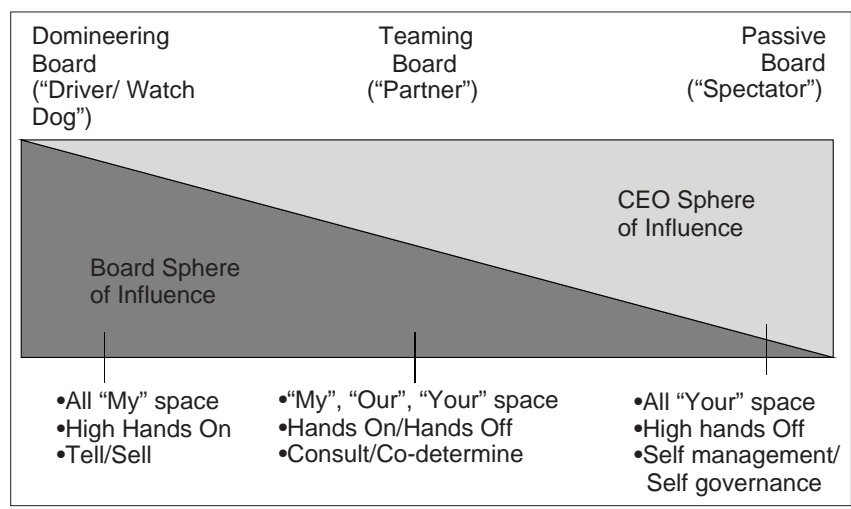

Figure 3: Different types of boards in terms of mandate

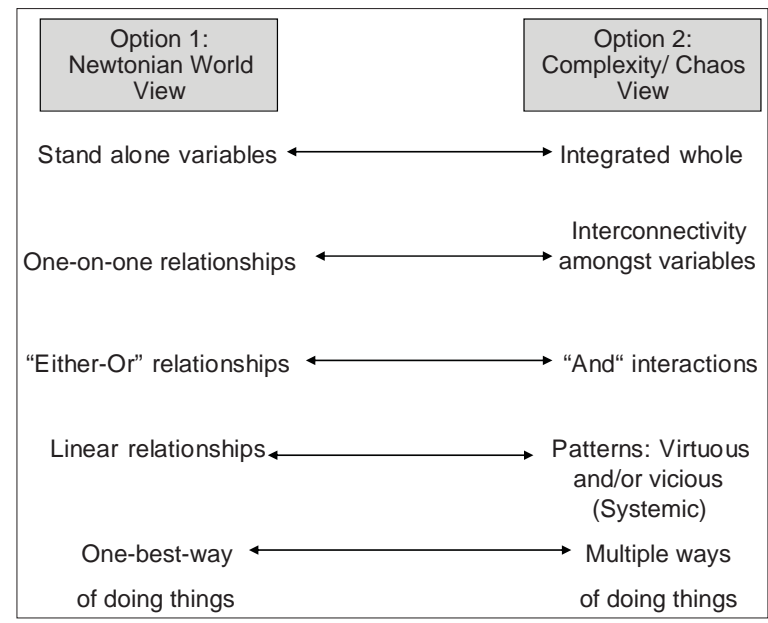

Figure 4: Possible sets of glasses through which to view the world 
combination of these dimensions: role-, achievement-, power-, or support-based identity (Harrison and Stokes, 1992). The corresponding counter/negative identities are: conformist (counter to role), runaway train (counter to achievement), feudal lord (counter to power), and old boys club/groupthink (counter to support) identities. Typically, a board's identity is a mixture of all four identities, though one identity is usually dominant. Figure 6 illustrates the above discussion with examples of the constructive identities.

Without explicitly addressing, reaching, and then maintaining, in open and honest dialogue, consensus on the above five questions regarding the board's operating framework, a board will be unclear on its positioning. Such vagueness and ambiguity will create, from the start, a potential breeding ground for the emergence of destructive board dynamics. In contrast, explicit answers to these questions will provide a board with a strong, sound operating framework for the other hardware elements, still to be discussed.

\section{Hardware element 2: Tasking}

Tasking refers to the scope of work as demarcated by the board for itself [Figure 2]. Put differently: what will be on the board's agenda and on what will the board spend its time and energy? In terms of these task dimensions, a board would set its agreed-upon goals, agenda, and expected outcomes. Tasking is directly affected by the vantage point adopted by the board: The possible dimensions of the world that need to be taken into consideration [Figure 5].

Figure 7 depicts what could typically be seen as a comprehensive and complete scope of work for a board (based on Bain, 2008; Conger, Lawler and Finegold, 2001; Garratt, 2003; 2010; Lawler, Finegold, Benson and Conger, 2002; Marcus, 2008; Minichilli, Zattoni and Zona, 2009; Murphy and McIntyre, 2007; Nadler, Behan and Nadler, 2006; Naidoo, 2009; Tricker, 2009; Zona and Zattoni, 2007). There is often a bias in boards to focus predominantly on Task 4 (Bain, 2008; Zona and Zattoni, 2007). The resource dependence view of a board's role providing access to the resources needed by the organisation (Daily, Dalton and Cannella, 2003; Tricker, 2009).

The sequence in which the four tasks have to be addressed during the course of a year needs to be established by the board in order to provide a logical, annual rhythm to its functioning. That is, dealing with the right tasks at the right time in the right order. One example is considering the organisation's strategy before reviewing the budget that needs to support the strategy (see the hardware element: design below).

\section{Hardware element 3: Design}

This element pertains to the way in which the board has been designed (or configured) to function, its operating logic
[Figure 2], assuming that the tasking hardware element that demarcates the work to be done by the board is in place. Design thus deals with how the board is structured and will function (cf. Bain, 2008; Nadler, Behan and Nadler, 2006; Naidoo, 2009).

Board design typically embraces aspects such as the following (Bain, 2008; Finegold, Benson and Hecht, 2007; MacAvoy and Millstein, 2003; Nadler, Behan and Nadler, 2006; Payne, Benson and Finegold, 2009; Petrovic, 2008;

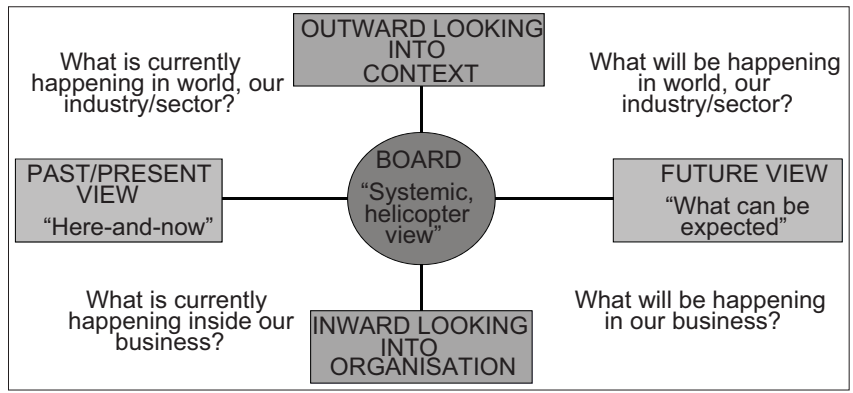

Figure 5: Possible dimensions of the world to be considered by the board

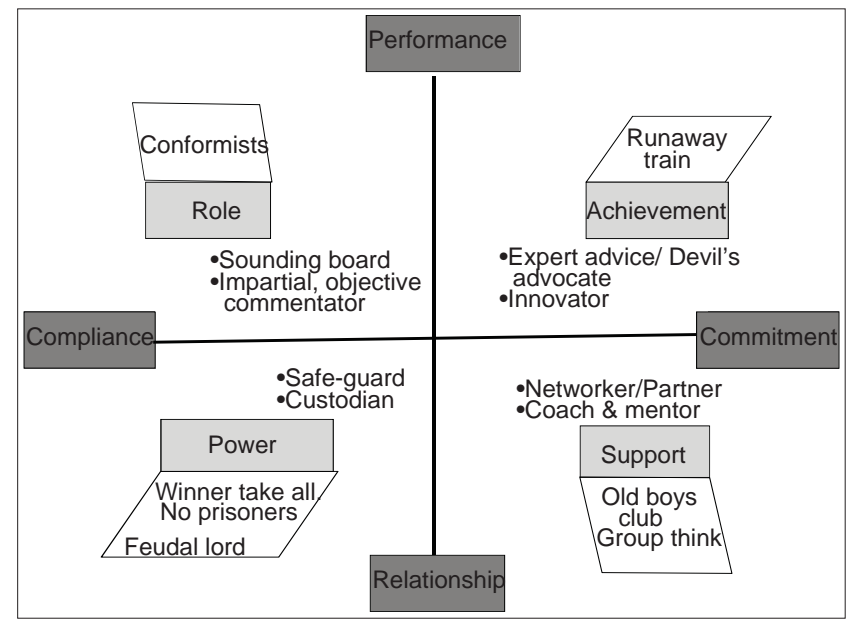

Figure 6: Possible board identities

\begin{tabular}{|c|c|c|}
\hline 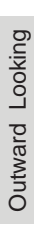 & $\begin{array}{l}\text { Task 1 } \\
\text { Stakeholder Engagement } \\
\text { \& Accountability } \\
\text { - Stakeholder Relationship } \\
\text { - Management \& Goodwill } \\
\text { - Company Image / Reputation } \\
\text { - } \text { Networking \& Brokering } \\
\text { Fiduciary, Legal \& Ethical } \\
\text { Compliance / Obligations }\end{array}$ & \begin{tabular}{ll} 
& \multicolumn{1}{c}{ Task 2} \\
& Strategic Direction \& Philosophy \\
- & Contextual Trends \\
- & Opportunities \& Threats \\
- & Objegy Formulation \& Execution \\
- & Values, Beliefs, Norms
\end{tabular} \\
\hline & $\begin{array}{l}\text { Task 4 } \\
\text { Organisational \& Management } \\
\text { Performance } \\
\text { - Resource Requirements, } \\
\text { Procurement \& Deployment } \\
\text { - Benchmarking } \\
\text { - Organisational\& Management } \\
\text { Performance Model \& Metrics } \\
\text { - Policies \& Standards } \\
\text { - Strengths \& Weaknesses } \\
\text { - Organisational Enablers \& } \\
\text { Barriers }\end{array}$ & $\begin{array}{l}\text { Task } 3 \\
\text { Organisational \& Leadership } \\
\quad \text { Continuity } \\
\text { - } \\
\text { Business Risk Identification \& } \\
\text { Mitigation Management } \\
\text { Key Talent Pool } \\
\text { - Compliance / Performance Checks } \\
\text { \& Balances } \\
\text { Core Organisational Competencies/ } \\
\text { Capabilities } \\
\text { - Strategic Clients \& Suppliers }\end{array}$ \\
\hline & Past / Pre & Future Orientation \\
\hline
\end{tabular}

Figure 7: Typical scope of work for a board 
Van Ees, Gabrielsson and Huse, 2009): the demarcation and definition of board roles; the division of work through work portfolios being allocated to board members; the subcommittee structure and composition of the board (these are usually, to a lesser or greater extent, covered by codes); the structuring of the board's agenda; the annual rhythm of when what items are put on the board's agenda; the board's work processes, procedures, and mode of working during and between meetings; information flow; decision-making rules, rights, and styles; and stakeholder management and interaction.

If a deliberate, systematic, and explicit design process has not been followed to properly and explicitly design the board's operating logic, the board will have been set up for failure from the outset. Chaos and confusion will reign due to the absence of a proper operating logic: It will be unclear what has to be deliberated when and by whom with what authority, accountability, and responsibility. Fertile soil will have been created for destructive and unhealthy board dynamics to germinate and flourish.

\section{Hardware element 4: Profile}

Profile as a hardware element [Figure 2], also referred to in the literature as board demographics or composition, pertains to the desired competencies of board members as individuals and that of the board overall. What total set of competencies must a board have at its disposal as a function of the above-discussed hardware elements of positioning, tasking, and design (Petrovic, 2008; Vandewaerde, Voordeckers, Lambrechts and Bammens, 2011)?

In the first instance, a decision must be made regarding the number of board members to serve on the board, i.e. the size of the board. A board should be large enough to provide the necessary competencies, but small enough to function effectively as a team. Related to the question of size is the issue of the ratio between outsiders (non-executive directors) and insiders (executive directors) in order to ensure independent views (Bain, 2008; Finegold, Benson and Hecht, 2007; Naidoo, 2009; Petrovic, 2008; Zona and Zattoni, 2007) - a hotly contested issue in most corporate codes. However, less strongly contended in these codes is the issue of stakeholder diversity and representivity on the board to ensure the necessary heterogeneity of the board. This issue should also be included in the consideration of the board profile (Bain, 2008; Conger, Lawler and Finegold, 2001; Johnson, Ellsrand and Daily, 1996; Minichilli, Zattoni and Zona, 2009; Payne, Benson and Finegold, 2009; Petrovic, 2008).

A comprehensive competency model for a board, covering: (i) Knowledge and skills, (ii) experience and expertise, (iii) personal attributes, (iv) interpersonal, teaming, and organizational abilities, (v) leadership/management abilities, (vi) wisdom, (vii) ethical abilities, and (viii) the ability to function at the requisite level of work required by the complexity of the work to be handled by the board - the contextual complexity of the organization - needs to be crafted and validated for a board (cf. Bain, 2008; Conger, Lawler and Finegold, 2001; Coulson-Thomas, 2009; Murphy and McIntyre, 2007; Nadler, Behan and Nadler, 2006; Payne, Benson and Finegold, 2009|. All of the above need to be viewed from the perspective that the board does not lead and manage the organization, but oversees its actions (Garratt, 2003).

The board competency model must find the middle ground between current and future competencies requirements. Important to consider is whether the board members, jointly and severally, have the required breadth and depth of competencies as prescribed in the competency model. Board members must be selected, inducted, trained, and developed against this model through a robust, rigorous, and well-mapped process. Associated with these processes is the planning of board member succession to ensure continuity.

Frequently, no or an unclear competency model exists for individual work portfolios and the board as a whole. If such a model does exist, it is often biased towards hard, tangible competencies, e.g., knowledge and skills, and experience and expertise. Soft, intangible competencies are not considered and/or are assumed to be present by default, e.g., personal attributes, ethical abilities, or leadership/ management abilities. There may even be a bias with respect to certain types of hard competencies - e.g., financial or operational - instead of soft competencies such as people management and stakeholder management. The requisite contextual complexity competencies are hardly, if ever, addressed, also in the board literature. In this scenario, board deliberations and decisions will be driven by and slanted towards the competencies present in the board.

Furthermore, no or little thought is given during the consideration of new board members to how their selection will contribute towards the overall competency set required by the board, both in terms of breadth and depth. This may result in a competency skewness on the board emerging over time, because only certain types of board members with certain competencies will be selected. The fact that the selection of board members is a politically-influenced election (or even nomination) process by stakeholders, as discussed above, can also significantly increase the chances that board members are selected for many reasons other than what a board needs in terms of its desired competency mix.

Without an ongoing, comprehensive competency profileperson match at both the individual and the overall board level, the board will be set up for failure because it will be unable to perform at the expected level, as it will lack mission-critical competencies. The board will also lack the confidence to act. Again, fertile soil will have been prepared for destructive and unhealthy board dynamics to germinate. 


\section{Hardware element 5: Ethics}

This hardware element encompasses what is prescribed and laid down as acceptable and unacceptable conduct by board members, jointly and severally [Figure 2]. This element contains formalised and explicit prescriptions regarding the conduct of board members and the board as a whole. Hence the inclusion of ethics as part of a board's hardware. Most, if not all, boards have a code of ethics and/or conduct - where the latter is based on the former - because the desirability of having such a code(s) is supported by the majority, if not all, corporate governance codes (e.g., King III, 2009; Naidoo, 2009).

From a board dynamics perspective, the issue is not the existence of a code(s) of ethics/conduct or not. The issue is rather what underlying core values inform and provide the basis for the code with its prescriptions. A board therefore needs to reach consensus on a fundamental level on what core values will direct and guide the board's and its members' conduct Brountas, 2004. There is also the additional complication of culturally diverse boards made up of members with significantly different value sets, or similar values but with vastly different acceptable and unacceptable behaviours associated with those values (Chan and Cheung, 2008).

Typically, core values of a board are: Stewardship: Looking after others' interests as if they were our own; Integrity: Acting in an honest, consistent, and trustworthy manner; Fairness: Being just and equitable in dealings; Accountability: Taking full responsibility for actions; and Transparency: Being open and accessible about the Why?, What?, and How? of actions (Garratt, 2003; King III, 2009; Naidoo, 2009; Rezaee, 2009).

Only once consensus on such core values has been reached can these agreed-upon values be operationalised into a code of ethics/conduct (Bain, 2008). A further issue is that these code(s) should not take on the form of a mechanical listing of acceptable/unacceptable conduct by which board members must abide in a 'tick box' fashion.

In the absence of board consensus on core values, the code of ethics/conduct becomes an imposed compliance tool bereft of any real appeal and meaning, continuously expanded in a futile and desperate effort to cover each and every ethical issue, contingency, and exception as it arises.
Without the benefit of an intense value sharing and embedding process by the board in order to arrive at a shared set of core values with the associated acceptable and unacceptable conduct contributed by everyone, a board may end up in endless, intense, and soul-destroying debates regarding the acceptability or not of the specific conduct of board members. Symptoms rather than causes will be addressed in a checklist fashion. Under these conditions, the code of ethics/conduct will probably not be worth the paper on which it is printed.

\section{CONCLUSION}

Part 1 of this article addressed the unique character of a board as a group that has to become a team; the "performance space" of a board; and the hardware of the board set-up: the formal aspects of a board's functioning that define and frame a board's role and mode of working.

The hardware of the board set-up (depicted graphically in Figure 2) defines upfront the playing field with game plan for the effective functioning of a board. If the playing field and game plan are unclear and/or under contention, the necessary preconditions for constructive and healthy board dynamics are severely compromised even before the software, the players and the game of the board set-up, is addressed. The core thrust of the above discussion centred around the critical need for a board to address its hardware through an upfront, systematic, and consensus-seeking process in order to create the necessary formal preconditions for constructive and healthy board dynamics.

Part 2 of this article will address the software of the board set-up, the evolutionary life cycle stages of board development, and board performance outcomes.

\section{REFERENCES}

References are included at the end of Part 2.

How to cite this article: Veldsman TH. The soft underbelly of corporate governance (Part 1): The hardware of board dynamics. Afr J Bus Ethics 2012;6:56-64.

Source of Support: Nil, Conflict of Interest: None declared

\section{AUTHOR}

Theo has extensive research and development, as well as consulting experience, gained over the past 35 years, in strategy formulation and implementation, strategic organisational change, organisational (re)design, team building, leadership/management development, and strategic people management. He is the author of about 180 reports/articles and authored a book titled "Into the People Effectiveness Arena - Navigating between chaos and order." He has also contributed eight book chapters on, respectively, organisational culture, organisational change interventions, strategic talent management, organisational partnering, learning and development leading practices, people competencies, the people professional in emerging countries, and the meta-theory of industrial and organisational psychology. 
Reproduced with permission of the copyright owner. Further reproduction prohibited without permission. 